\title{
Case Report,
}

\section{Cat-Scratch Disease Pneumonia: An Atypical Presentation}

\author{
Fotis Konstantinou ${ }^{1}$, Ioanna Skrapari ${ }^{2}$, Asimoula Megkou ${ }^{3}$, Evangelos Kokkinakis ${ }^{4}$ \\ ${ }^{1,2,3,4}$ Internal Medicine Physician at the First Internal Medicine Department, Evangelismos General Hospital, \\ Ypsilantou 45-47, Postal Code 10676, Athens, Greece
}

\begin{abstract}
:
Purpose: Cat-scratch disease is caused by Bartonella henselae infection and it commonly presents in children with a mild cutaneous lesion and adjacent lymphadenitis. It has rarely been observed that it can present as a disseminated infection, such as encephalitis or pneumonia. We present a case report of a 35-year old, immunocompetent, patient who suffered pneumonia and encephalitis, resulting from Bartonella henselae infection. We also present a review of the literature published regarding this rare complication.

Methods: We've searched the literature in the databases of Pubmed and Google Scholar to find articles that report pulmonary presentations of cat-scratch disease.

Results: We've found only 16 other reported similar cases with pulmonary involvement in cat-scratch disease.

Conclusions: Pulmonary presentation in cat-scratch disease is an uncommon presentation of a common disease, and it should be ruled out, even in cases it seems unlikely.
\end{abstract}

Key words: Bartonella, Cat, Pneumonia, Encephalitis, Lymphadenitis

Abbreviations: Computed Tomography (CT), Cerebrospinal Fluid (CSF), Indirect Fluorescence Assay (IFA), Enzyme Immunosorbent Assay (EIA), Polymerase Chain Reaction (PCR)

\section{Introduction:}

Cat-scratch disease was first described by Debré [1] in 1954 and has since been examined in various reviews, as methods of diagnosis have evolved. The most common causative agent is Bartonella henselae (formerly Rochalimaea henselae), although other similar organisms have been reported to be causative, less common, such as Afipia felis [2] and Bartonella clarridgeiae [3]. It is transmitted to human via contact of broken skin areas or mucosal surfaces with cat saliva or after scratch or bite from an infected cat, cat fleas, while there are reports of cases with exposure to dogs [4]. The most common clinical feature is a cutaneous lesion at the site of inoculation, often manifested with a vesicular, erythematous, and papular phase, accompanied by regional tender lymphadenopathy and fever. Atypical manifestations have been described, in up to $33 \%$ of patients older than 60 years, compared to $14 \%$ in younger patients [5] and include encephalitis and endocarditis, resulting from disseminated infection. Other atypical manifestations are Parinaud's oculoglandular syndrome, neuroretinitis, erythema nodosum, and granulomatous hepato-splenitis, myalgias, arthralgias and osteomyelitis. Bacillary angiomatosis and peliosis hepatis are complications only found in immunocompromised patients. Pertaining respiratory complications, only rare cases have been reported, including pneumonia, pleural effusion or pleural thickening, with an unknown prevalence. In the past, skin testing was used for diagnosis, but it has now been replaced by serology tests, including Indirect Fluorescence Assay (IFA) and Enzyme Immunosorbent Assay (EIA). Polymerase Chain Reaction (PCR) amplification testing for Bartonella DNA in the affected tissues can confirm 
Fotis Konstantinou et all. / Cat-Scratch Disease Pneumonia: An Atypical Presentation.

the diagnosis, while PCR in the serum has low sensitivity [6]. Identification by culture is very difficult because it requires specific laboratory conditions. The lymph node histopathology usually reveals lymphoid hyperplasia, microabscess formation and stellate granulomas with acellular and necrotic centers and peripheral accumulation of lymphocytes and histiocytes.

Florin et al [4] revised the criteria for diagnosis in 2008, requiring three of the following four:

1. History of contact with a cat with or without primary skin inoculation

2. Exclusion of other causes of lymphadenopathy

3. Positive serology

4. Lymph node biopsy showing microabscess or granulomas and positive Warthin-Starry silver stain.

Table 1: Laboratory Workup

\begin{tabular}{|c|c|}
\hline WBC & $11640 \times 10 / \mu \mathrm{L}$ \\
\hline $\mathrm{NE}$ & $8260 \times 10 / \mu \mathrm{L}$ \\
\hline LY & $2390 \times 10 / \mu \mathrm{L}$ \\
\hline MONO & $910 \times 10 / \mu \mathrm{L}$ \\
\hline BASO & $40 \times 10 / \mu \mathrm{L}$ \\
\hline $\mathrm{EO}$ & $40 \times 10 / \mu \mathrm{L}$ \\
\hline HCT & $41 \%$ \\
\hline $\mathrm{HB}$ & $13.7 \mathrm{~g} / \mathrm{dl}$ \\
\hline PLT & $462000 \times 10 / \mu \mathrm{L}$ \\
\hline $\mathrm{GIU}$ & $148 \mathrm{mg} / \mathrm{dl}$ \\
\hline URE & $31 \mathrm{mg} / \mathrm{dl}$ \\
\hline CRE & $1 \mathrm{mg} / \mathrm{dl}$ \\
\hline NA & $135 \mathrm{mg} / \mathrm{dl}$ \\
\hline $\mathrm{K}$ & $4.6 \mathrm{mg} / \mathrm{dl}$ \\
\hline $\mathrm{TP}$ & $7.3 \mathrm{mg} / \mathrm{dl}$ \\
\hline AST & $21 \mathrm{mg} / \mathrm{dl}$ \\
\hline ALT & $25 \mathrm{mg} / \mathrm{dl}$ \\
\hline ALP & $79 \mathrm{mg} / \mathrm{dl}$ \\
\hline GGT & $140 \mathrm{mg} / \mathrm{dl}$ \\
\hline TBIL & $0.42 \mathrm{mg} / \mathrm{dl}$ \\
\hline LDH & $305 \mathrm{mg} / \mathrm{dl}$ \\
\hline AMY & $45 \mathrm{mg} / \mathrm{dl}$ \\
\hline
\end{tabular}

\begin{tabular}{|c|c|}
\hline CRP & $17.4 \mathrm{mg} / \mathrm{dl}$ (normal values 0-0.4 mg/dl) \\
\hline CSF cells & 19 (Poly:15, Lympho:4) \\
\hline CSF Glu & $68 \mathrm{mg} / \mathrm{dl}$ \\
\hline CSF TP & $36.1 \mathrm{mg} / \mathrm{dl}$ \\
\hline Pleural fluid cells & 1100 (Poly: $12 \%$, Lympho: $80 \%$, Mono: \\
& $4.1 \mathrm{mg} / \mathrm{dl}$ \\
\hline Pleural fluid TP & $171 \mathrm{mg} / \mathrm{dl}$ \\
\hline Pleural fluid LDH & \\
\hline
\end{tabular}

Abbreviations: WBC: White Blood Cell Count, NE: Neurophil Count, LY: Lymphocyte Count, MONO: Monocyte Count, BASO: Basophile Count, EO: Eosinophil Count, HCT: Hematocrit, HB: Hemoglobin, PLT: Platelet Count, GLU: Glucose, URE: Urea, CRE: Creatinine, NA: Sodium, K: Potassium, TP: Total Proterin, AST: Aspartic Aminotransferase, ALT: Alanine Aminotransferase, ALP: Alkaline Phosphatase, GGT: Gamma-glutamyltransferase, TBIL: Total Bilirubin, LDH: Lactic Dehydrogenase, AMY: Amylase, CRP: C-Reactive Protein, CSF: Cerebrospinal fluid

\section{Case report:}

A 35-year-old male patient came to the emergency department with loss of consciousness and first onset generalized epileptic seizures. He didn't have any known health problems and he is considered immunocompetent. His relatives reported that for 20 days he had been suffering from high grade fever and night sweats. He also complained about painful swelling in the axilla and elbow of the left arm. He had seen a doctor for that who prescribed common antibiotics and had visited the emergency department once more, 5 days ago, but then decided to leave against medical advice. Upon his arrival at the emergency department he developed generalized tonic seizures, which were followed by interchanges of consciousness between coma, lethargy and a confusional, disoriented state. He also had tachypnea and low arterial oxygen saturation. His brain CT scan was normal, and a lumbar puncture was conducted. The results from the cerebrospinal fluid (CSF) indicated towards encephalitis and they are shown on table 1. A CT scan of the lungs revealed bilateral pleural effusion and a bilateral nodular pattern of opacities in the upper pulmonary lobes (Figure 1), while the CT scan of the abdomen only revealed a mild enlargement of the spleen. He was administered anti-seizure treatment with Levetiracetam, antimicrobial coverage for common central nervous system pathogens and required low flow oxygen administration. Pleural fluid was sent for analysis after thoracentesis, which revealed 
Fotis Konstantinou et all. / Cat-Scratch Disease Pneumonia: An Atypical Presentation.

lymphocytic exudate. An ultrasound of the left elbow revealed enlargement of epitrochial lymph nodes, and a biopsy revealed abscess formation and inflammation without specific characteristics. The abscess in the elbow and axillar areas were both drained subcutaneously and were sent for microbiologic analysis.

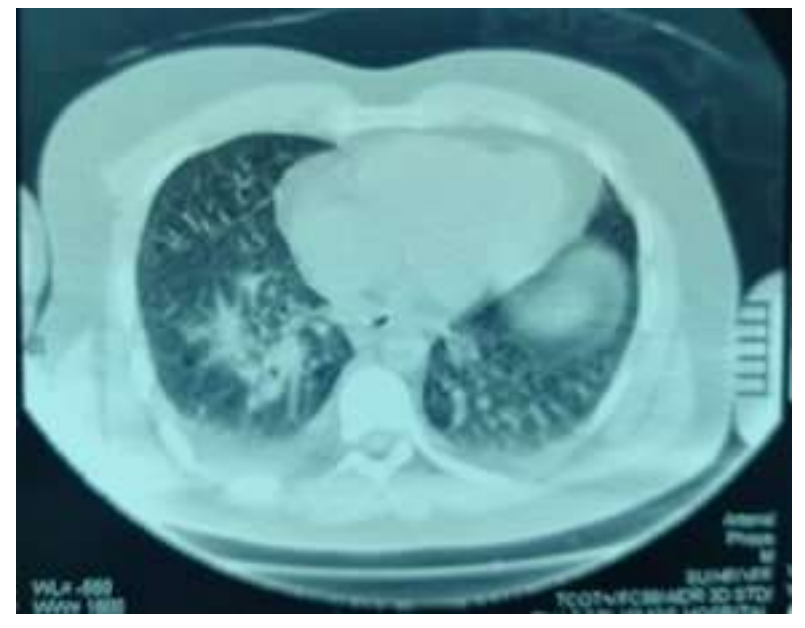

Figure 1: Chest CT scan of a patient with pneumonia of Bartonella Henselae. Nodular pulmonary infiltrates and pleural effusion can be seen.

During the second day of inpatient care, he showed signs of recovery of consciousness, with alertness and orientation, with full recovery of consciousness on the fourth day. He developed worsening crackles at auscultation of the lungs and required oxygen administration for at least ten more days. A second CT of the chest revealed improvement of opacities in the lung parenchyma with persistent pleural effusions. From the laboratory workup, increased inflammatory markers were observed, with increased neutrophil count and C-reactive protein. A thorough laboratory workup for viral and bacterial pathogens' antibodies was negative, and the cultures and direct stains of blood, CSF, pleural fluid and abscess drainage fluid were negative.

The patient remembered that he had petted a stray cat and kittens about a month before the onset of the symptoms and that the cat scratched him on his left hand. The IgG antibody tests for Bartonella henselae came out positive at a titer of 1:512 which was doubled six days later, and at that time the $\operatorname{IgM}$ antibodies were found positive as-well. His antibiotic regimen was changed to Doxycyclin and Rifampicin and the fever and the rest of clinical signs were attenuated gradually. The patient was discharged thirty days later feeling well.

\section{Literature review on Cat-scratch disease associated pneumonia:}

The purpose of this article is to review the pulmonary manifestations of cat-scratch disease in the literature. Pulmonary manifestations can include pneumonia, appearing on CT scans as opacities, pulmonary nodules and reticulonodular or interstitial pulmonary infiltrates. Pleural effusions and pleural thickening are often described, and when available, Bartonella DNA is detected with PCR after thoracentesis. 16 patients are described in this review with pulmonary manifestations of Bartonella henselae disease, 3 females and 13 males. 7 of them are children aged 3-12 years old and the rest are adults. 5 of them were immunocompromised and 1 of them suffered from type 2 diabetes mellitus, which can be regarded as a risk factor for infections. The rest did not have any significant medical history and were considered immunocompetent. Patient characteristics and clinical signs and symptoms are presented in table 2. Only 4 patients had developed both central nervous system and pulmonary involvement, like the patient in this case report. Two cases were complicated with septic shock and one of them died; surprisingly, only suffering from type 2 diabetes as an underlying disease. Whitman \& Krafte-Jacobs [22] suggest that bacterial endotoxins and immune complex deposition are implicated in the pathophysiology of cat-scratch disease associated pulmonary involvement. In 1998, Margileth \& Baehren [3] reported a case of chest-wall abscess, which started as a focal myositis between the pectoralis major and minor, with positive serologic tests for Bartonella clarridgeiae, without any evidence of pulmonary involvement, though. Biddinger et al [23] describe a case of invasive endocarditis possibly due to Bartonella henselae with pulmonary infiltrates in the right middle lobe, but they suggest that it was more likely to be a result of asymmetric pulmonary edema, rather than pneumonia.

\section{Discussion:}

We present an uncommon manifestation of a rather common disease. To our knowledge, only 16 similar cases of pulmonary involvement in catscratch disease were reported in the past. Positive antibody titers, along with the exclusion of other causes via a thorough microbiological workout, placed the diagnosis in our patient. Unfortunately, neither PCR testing nor Warthy-Stain silver stain were available in our hospital. As we were able to witness it in our patient, disseminated infection of Bartonella henselae, follows a rather slow course of response to antibiotic treatment. The axillar and elbow abscesses required subsequent drainage and 
Fotis Konstantinou et all. / Cat-Scratch Disease Pneumonia: An Atypical Presentation.

he was treated with oral antibiotics for a total of 6 months to completely recover. This case was presented to us amidst the 2020 pandemic of SARS-COVID-19 [24]. Although most signs in our patient didn't fit the clinical profile of COVID19 disease, the persistent respiratory disease, along with high grade fever, placed a high suspicion for COVID-19. Thus, the patient was transferred, at first, to the COVID-19 treatment unit, until two PCR tests from nasopharyngeal swab came out negative. We'd like to report this as a take-home message, and as a recommendation towards clinicians, during this pandemic; even though COVID-19 might be a prevalent disease that could fit a certain clinical profile, clinicians should be alert for other diseases as-well, whose diagnosis and treatment must not be delayed.

\section{Declarations:}

- Funding: This study received no funding.

- Conflict of Interest: Authors Fotis Konstantinou, Ioanna Skrapari, Asimoula Megkou and Evangelos Kokkinakis declare that they have no conflict of interest.

- Availability of data and material: All data generated or analyzed during this study are included in this published article.

\section{References:}

[1.] Debré R, Job JC (1954) La maladie des griffes du chat (Cat Scratch Fever). Acta Paediatr https://doi.org/10.1111/j.1651-

2227.1954.tb04042.x

[2.] Cabot RC, Scully RE, Mark EJ (1992) Case 22-1992. N Engl J Med 327(22):1599-601. doi:10.1056/NEJM199211263272215

[3.] Margileth AM, Baehren DF (1998) ChestWall Abscess Due to Cat- Scratch Disease (CSD) in an Adult with Antibodies to Bartonella clarridgeiae: Case Report and Review of the Thoracopulmonary Manifestations of CSD. Clin Infect Dis 27(2):353-7. doi:10.1086/514671

[4.] Florin TA, Zaoutis TE, Zaoutis LB (2008) Beyond Cat Scratch Disease: Widening Spectrum of Bartonella henselae Infection. Pediatrics 121(5):e1413-25. doi:10.1542/peds.2007-1897

[5.] Ronen BA, Moshe E, Boaz A, et al. (2005) Cat-Scratch Disease in Elderly Patients. CID 41(7):969-974. https://doi.org/10.1086/432934
- Authors' contributions: All authors contributed to the study conception and design. Material preparation, data collection and analysis were performed by Fotis Konstantinou, Ioanna Skrapari, and Asimoula Megkou. The first draft of the manuscript was written by Fotis Konstantinou and all authors commented on previous versions of the manuscript. Evangelos Kokkinakis was a supervisor during the procedure and guided the team towards data collection and writing the manuscript. All authors read and approved the final manuscript.

- Ethical approval: This article does not contain any studies with human participants performed by any of the authors.

- Consent to participate: Informed consent was obtained from all individual participants included in the study.

- Consent to publish: The participant has consented to the submission of the case report to the journal.

[6.] Vermeulen MJ, Diederen BMW, Verbakel H, Peeters MF (2008) Low sensitivity of Bartonella henselae PCR in serum samples of patients with cat-scratch disease lymphadenitis. J Med Microbiol 57(Pt 8):1049-1050. 10.1099/jmm.0.2008/001024-0

[7.] Sheldon GC, Smellie H (1957) Cat-scratch Disease with Pneumonia. BMJ 2(5042):446447. doi:10.1136/bmj.2.5042.446

[8.] Katner HP, Treen B, Pankey GA, Glasgow S, Cortez LM, Dalovisio J (1986) Pleural Effusion and Anicteric Hepatitis Associated with Cat-Scratch Disease. Chest 89(2):302-3. doi:10.1378/chest.89.2.302

[9.] Margileth AM, Wear DJ, English CK (1987) Systemic Cat Scratch Disease: Report of 23 Patients with Prolonged or Recurrent Severe Bacterial Infection. J Infect Dis 155(3):390-402. doi:10.1093/infdis/155.3.390

[10.] Black JR, Herrington DA, Hadfield TL, Wear DJ, Margileth AM, Shigekawa B (1989) Life-threatening cat-scratch disease in an immunocompromised host. Arch Intern 
Med

146:394-

6. doi:10.1001/archinte. 1986.003601402380 35

[11.] Schlossberg D (1989) Culture-Proved Disseminated Cat-Scratch Disease in Acquired Immunodeficiency Syndrome. Arch Intern Med 149(6):1437-9. doi:10.1001/archinte.1990.00390170140031

[12.] Karanyi, K (1994) Fever, Back Pain and Pleural Effusion in a Four-Year-Old Boy. Pediatr Infect Dis J 13(7):657-672.

[13.] Caniza MA, Granger DL, Wilson KH, et al (1995) Bartonella henselae: Etiology of Pulmonary Nodules in a Patient with Depressed Cell-Mediated Immunity. Clin Infect Dis 20(6):1505-11. doi:10.1093/clinids/20.6.1505

[14.] Abbasi S, Chesney PJ (1995) Pulmonary Manifestations of Cat-Scratch Disease; a Case Report and Review of the Literature. Pediatr Infect Dis J 14(6):547-8. doi: 10.1097/00006454-199506000-00014

[15.] Marseglia GL, Monafo V, Meloni F, Martini A, Burgio GR, Marone P (2001) Asymptomatic persistent pulmonary infiltrates in an immunocompetent boy with cat-scratch disease. Eur J Pediatr 160(4):2601. doi:10.1007/s004310000697

[16.] Takeda N, Ishiwada N, Fukasawa N, et al (2007) Pediatric Pneumonia, Pleural Effusion, and Pericarditis Following Cat Scratch Disease and Serological Crossreactions Among Bartonella henselae and Rickettsia japonica Determined by Indirect Fluorescence Antibodies, Kansenshogaku Zasshi. J.J.A. Inf. D. 81:206-209. doi: 10.11150/kansenshogakuzasshi1970.81.206

[17.] Dutta A, Schwarzwald HL, Edwards MS (2010) Disseminated Bartonellosis
Presenting As Neuroretinitis In A Young Adult With Human Immunodeficiency Virus Infection. Pediatr Infect Dis J 29(7):675-7. doi:10.1097/INF.0b013e3181d60a6d

[18.] Brunetti E, Fabbi M, Ferraioli G, et al (2013) Cat-scratch disease in Northern Italy: atypical clinical manifestations in humans and prevalence of Bartonella infection in cats. Eur J Clin Microbiol Infect Dis 32(4):531-4. doi:10.1007/s10096-012-1769-5

[19.] Bandyopadhyay A, Burrage LC, Gonzalez BE (2013) Pulmonary Nodules in an Immunocompetent Child with Cat Scratch Disease. Pediatr Infect Dis J 32(12):1390-2. doi:10.1097/INF.0000000000000069

[20.] Rohr A, Ash R, Vadaparampil J, Hill J, Wetzel L (2016) Disseminated cat-scratch disease in an adult with selective $\operatorname{IgA}$ deficiency. Radiol Case Rep 11(2):54-7. doi:10.1016/j.radcr.2016.02.016

[21.] Knudson-Fitzpatrick T (2019) A Claw To the Lung: A Pulmonary Manifestation of Disseminated Bartonella Henselae. Chest 156(4)

[22.] Whitman BW, Krafte-Jacobs B (1995) Cat scratch disease associated with pleural effusions and encephalopathy in a child. Respiration doi:10.1159/000196417

[23.] Biddinger PD, Isselbacher EM, Fan D, Shepard JAO (2005) Case 5-2005. N Engl J Med 352(7):709-16

[24.] WHO (2020) WHO announces COVID-19 outbreak a pandemic. http://www.euro.who.int/en/healthtopics/health-emergencies/coronaviruscovid-19/news/news/2020/3/who-announcescovid-19-outbreak-a-pandemic. Accessed 28 April 2020

Table 2: A review of the literature on pulmonary manifestations in cat-scratch disease

\begin{tabular}{|l|l|l|l|l|}
\hline $\begin{array}{l}\text { Patient } \\
\text { characteristics }\end{array}$ & Year & $\begin{array}{l}\text { Clinical signs and } \\
\text { symptoms }\end{array}$ & Atypical manifestations & Diagnosis \\
\hline $\begin{array}{l}\text { Female, 46, } \\
\text { housewife }\end{array}$ & $1957[7]$ & $\begin{array}{l}\text { Fever, Headache, } \\
\text { Dyspnea, Enlarged } \\
\text { epitrocheal LN }\end{array}$ & $\begin{array}{l}\text { Consolidation of right lower } \\
\text { lobe, pleural reaction }\end{array}$ & Cat-scratch antigen skin test (+) \\
\hline $\begin{array}{l}\text { Male, 20, termite } \\
\text { technician }\end{array}$ & $1986[8]$ & $\begin{array}{l}\text { Fever, Enlarged } \\
\text { epitrocheal LN }\end{array}$ & $\begin{array}{l}\text { Mental confusion, increased } \\
\text { sleepiness }\end{array}$ & $\begin{array}{l}\text { Lymph node biopsy: Warthin-Starry } \\
\text { stain (+) }\end{array}$ \\
\hline
\end{tabular}


Fotis Konstantinou et all. / Cat-Scratch Disease Pneumonia: An Atypical Presentation.

\begin{tabular}{|c|c|c|c|c|}
\hline & & & $\begin{array}{l}\text { Anicteric hepatitis } \\
\text { Right pleural effusion }\end{array}$ & \\
\hline Male, 24 & $1987[9]$ & $\begin{array}{l}\text { Fever, Pleuritic } \\
\text { chest pain, Enlarged } \\
\text { left axillary LN }\end{array}$ & $\begin{array}{l}\text { Left apical pleural } \\
\text { thickening, Mediastinal mass } \\
\text { in the right posterior side }\end{array}$ & $\begin{array}{l}\text { Cat-scratch antigen skin test }(+) \\
\text { Mediastinal mass biopsy: necrotizing } \\
\text { granulomas, Warthin-Starry stain (-) }\end{array}$ \\
\hline $\begin{array}{l}\text { Male, 34, Renal } \\
\text { allograft recipient }\end{array}$ & $1989[10]$ & $\begin{array}{l}\text { Fever, Dry cough, } \\
\text { Headache, Enlarged } \\
\text { left epitrochial and } \\
\text { axillar LN }\end{array}$ & $\begin{array}{l}\text { Seizure, Bilateral infiltrates, } \\
\text { Septic shock }\end{array}$ & $\begin{array}{l}\text { Lymph node biopsy: Warthin-Starry } \\
\text { silver stain }(+)\end{array}$ \\
\hline Male, 27, HIV (+) & $1990[11]$ & $\begin{array}{l}\text { Fever, Diarrhea, } \\
\text { Enlarged left } \\
\text { epitrocheal and } \\
\text { axillary LN }\end{array}$ & $\begin{array}{l}\text { Pleural effusion, } \\
\text { Papilledema, Retinitis, Liver } \\
\text { abscess }\end{array}$ & $\begin{array}{l}\text { Lymph node biopsy: Warthin-Starry } \\
\text { stain }(+)\end{array}$ \\
\hline Male, 4 & $1994[12]$ & $\begin{array}{l}\text { Fever, Vomiting, } \\
\text { Right side } \\
\text { abdominal pain, } \\
\text { Enlarged left } \\
\text { axillary LN }\end{array}$ & $\begin{array}{l}\text { Left side pleural effusion and } \\
\text { pneumonia }\end{array}$ & $\begin{array}{l}\text { PCR of pleuritic fluid (+) } \\
\text { Serology antibody testing }(+)\end{array}$ \\
\hline $\begin{array}{l}\text { Female, } 19 \text {, renal } \\
\text { allograft recipient }\end{array}$ & $1995[13]$ & $\begin{array}{l}\text { Fever, Diarrhea, } \\
\text { Vomiting }\end{array}$ & $\begin{array}{l}\text { Bilateral pulmonary nodules } \\
\text { in the lower lobes, } \\
\text { retroperitoneal adenopathy, } \\
\text { Low-density lesion in the } \\
\text { spleen }\end{array}$ & $\begin{array}{l}\text { PCR on lung nodules biopsy } \\
\text { specimens }(+) \\
\text { Serology antibody testing (+) }\end{array}$ \\
\hline Male, 8 , & $1995[14]$ & $\begin{array}{l}\text { Fever, Vomit, } \\
\text { Enlarged left } \\
\text { axillary LN }\end{array}$ & $\begin{array}{l}\text { Seizures, Diffuse bilateral } \\
\text { interstitial infiltrates }\end{array}$ & $\begin{array}{l}\text { Indirect fluorescent antibody titers } \\
1: 512\end{array}$ \\
\hline Male, 11 & $1995[22]$ & $\begin{array}{l}\text { Fever, tachypnea, } \\
\text { Enlarged inguinal } \\
\text { LN }\end{array}$ & $\begin{array}{l}\text { Seizures, bilateral pleural } \\
\text { effusions }\end{array}$ & $\begin{array}{l}\text { Lymph node biopsy: Stellate abscess } \\
\text { Cat-scratch antigen skin test }(+)\end{array}$ \\
\hline Male, 6 & $2001[15]$ & $\begin{array}{l}\text { Fever, submaxillary } \\
\text { LN }\end{array}$ & $\begin{array}{l}\text { Multiple hypodense } \\
\text { hepatosplenic lesions, difuse } \\
\text { bilateral reticulonodular } \\
\text { pulmonary infiltrates }\end{array}$ & Positive serology testing \\
\hline Male, 3 & $2007[16]$ & Fever & $\begin{array}{l}\text { Pneumonia, pleural effusion, } \\
\text { and pericarditis }\end{array}$ & Serology antibody testing (+) \\
\hline Male, 21, HIV (+) & $2010[17]$ & $\begin{array}{l}\text { Fever, vomiting, } \\
\text { blurred vision }\end{array}$ & $\begin{array}{l}\text { Neuroretinitis, Peripheral } \\
\text { pulmonary nodules with } \\
\text { mediastinal } \\
\text { lymphadenopathy }\end{array}$ & $\begin{array}{l}\text { Lung biopsy: granuloma with } \\
\text { necrotic center } \\
\text { PCR (+) from biopsy sample } \\
\text { Serology antibody testing (+) }\end{array}$ \\
\hline Male, 12 & $2013[18]$ & Fever & $\begin{array}{l}\text { Bilateral reticulonodular } \\
\text { pulmonary infiltrates, } \\
\text { Multifocal hepatosplenic } \\
\text { granulomas }\end{array}$ & Serology antibody testing (+) \\
\hline Female, 3 & 2013 [19] & $\begin{array}{l}\text { Fever, Cough, } \\
\text { Diarrhea }\end{array}$ & $\begin{array}{l}\text { Scattered } 2-3 \mathrm{~mm} \text { nodular } \\
\text { densities throughout the } \\
\text { lungs } \\
\text { Focal hypodensities } \\
\text { throughout the liver and left } \\
\text { kidney }\end{array}$ & $\begin{array}{l}\text { Pulmonary biopsy: necrotizing } \\
\text { granulomas } \\
\text { PCR (+) from biopsy sample } \\
\text { Serology antibody testing (+) }\end{array}$ \\
\hline $\begin{array}{l}\text { Male, 51, selective } \\
\text { IgA deficiency }\end{array}$ & $2016[20]$ & $\begin{array}{l}\text { Right sided chest } \\
\text { pain }\end{array}$ & $\begin{array}{l}\text { Multiple pulmonary nodules, } \\
\text { Hypoenhancing } \\
\text { hepatosplenic lesions }\end{array}$ & $\begin{array}{l}\text { Lung biopsy: giant cell reaction, } \\
\text { caseation necrosis, Liver biopsy: } \\
\text { granulomatous hepatitis with } \\
\text { scattered non-necrotizing } \\
\text { granulomas } \\
\text { Serology antibody testing (+) }\end{array}$ \\
\hline Male, 44 , type 2 & $2019[21]$ & Hypoxia, Cough & Bilateral opacities, Left & Mediastinal lymph node biopsy: \\
\hline
\end{tabular}


Fotis Konstantinou et all. / Cat-Scratch Disease Pneumonia: An Atypical Presentation.

\begin{tabular}{|l|l|l|l|l|}
\hline diabetes & & $\begin{array}{l}\text { upper lobe pulmonary } \\
\text { nodule, Prominent } \\
\text { mesenteric, mediastinal, and } \\
\text { hilar lymph nodes }\end{array}$ & Serology antibody testing (+) \\
\hline Male, 35 & 2020 & $\begin{array}{l}\text { Hypoxia, Left } \\
\text { epitrochial and } \\
\text { axillar LN }\end{array}$ & $\begin{array}{l}\text { Epileptic seizures, Bilateral } \\
\text { opacities, nodules and } \\
\text { pleural effusions }\end{array}$ & Serology antibody testing (+) \\
$\begin{array}{l}\text { current } \\
\text { case } \\
\text { report }\end{array}$ & & & \\
\hline
\end{tabular}

